\title{
Protist grazing and viral lysis as prokaryotic mortality factors at Baltic Sea oxic-anoxic interfaces
}

\author{
Ruth Anderson $^{1}$, Christian Winter ${ }^{2}$, Klaus Jürgens ${ }^{1, *}$ \\ ${ }^{1}$ Leibniz Institute for Baltic Sea Research, Department of Biological Oceanography, Seestrasse 15, \\ 18119 Rostock-Warnemünde, Germany \\ ${ }^{2}$ Department of Marine Biology, University of Vienna, Althanstrasse 14, 1090 Vienna, Austria
}

ABSTRACT: Interface zones between oxic and anoxic water masses (pelagic redoxclines) host highly active prokaryotic communities, mediating important biogeochemical transformations. However, for marine pelagic redoxclines almost no knowledge exists on the magnitude of the loss processes affecting these prokaryotic communities. We assessed the importance of protist grazing and viral lysis as prokaryotic mortality factors for 2 central Baltic Sea redoxclines using a combination of microscopy and experimental community manipulation techniques. Our results demonstrate that protist grazing dominated prokaryotic mortality at suboxic (<30 $\mathrm{\mu mol} \mathrm{l}^{-1}$ oxygen) and oxygen-hydrogen sulphide interface depths, with 50 to $100 \%$ of prokaryotic standing stocks grazed daily, compared to 2 to $20 \%$ of virally infected cells. Grazing was mediated by 2 different protist associations, viz. dinoflagellates and Strombidiumlike ciliates in the suboxic zone, and larger ciliates (cf. Mesodinium, Metacystis spp., cf. Coleps and unidentified morphotypes) at the oxygen-hydrogen sulphide interface. In contrast, heterotrophic nanoflagellates $(\mathrm{HNF})$ played a minor role, generally grazing $<5 \%$ daily of prokaryotic standing stocks. Thus, these redox zones show major differences in microbial food web structure when compared to surface waters, with ciliates and dinoflagellates constituting the major bacterivores instead of HNF. At sulphidic depths, grazing was below the detection limit, and the frequency of virally infected cells decreased, leaving the identity of the major prokaryotic mortality factor at these depths unresolved.

KEY WORDS: Protist - Grazing · Viral lysis · Suboxia · Anoxia $\cdot$ Redoxcline $\cdot$ Baltic Sea written consent of the publisher

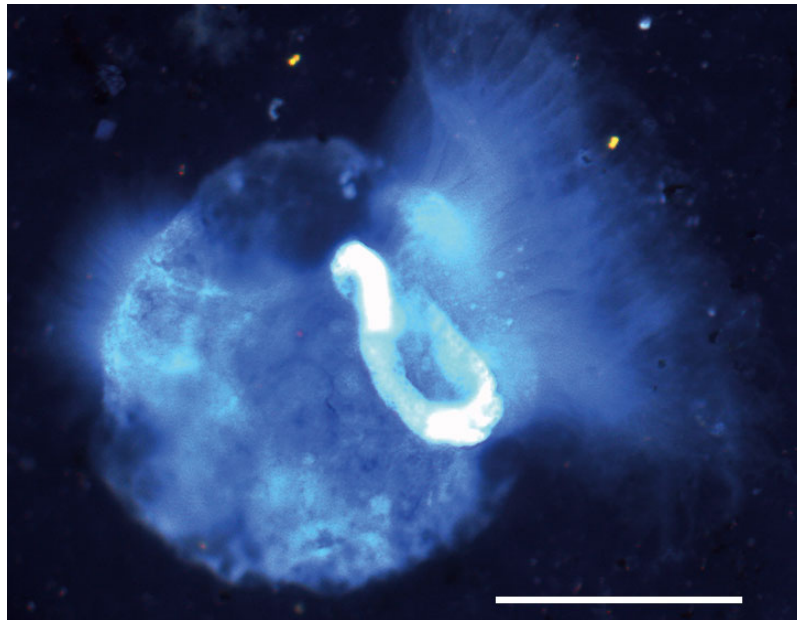

Epifluorescence microscopy photograph of a ciliate (cf. Strombidium) typically found at Baltic Sea oxic/anoxic interfaces. Scale bar $=10 \mu \mathrm{m}$.

Photo: R. Anderson

\section{INTRODUCTION}

Protists have long been recognized as fundamental components of microbial food webs in oxygenated marine and freshwater environments (reviews by Sherr \& Sherr 2002, Jürgens \& Massana 2008). Phototrophic unicellular eukaryotes can contribute a significant fraction of primary production (Worden et al. 2004), whereas phagotrophic protists, especially heterotrophic nanoflagellates (HNF), regulate the abundance, activity and composition of prokaryotic communities (Jürgens \& Matz 2002, Pernthaler 2005, Montagnes et al. 2008). Additionally, they act as 
important agents in nutrient remineralization and, as prey, serve as a fundamental link to higher trophic levels (Zöllner et al. 2009). However, their abundance and ecological role in other environments, such as sediments or suboxic (here defined as $\leq 30 \mu \mathrm{M}$ $\mathrm{O}_{2}$ ) to anoxic water masses, remains understudied.

One such environment of special interest is the interface zone between oxic and anoxic/sulphidic water masses, or pelagic redoxclines, in brackish and marine systems. These redox zones are found worldwide, e.g. in the Baltic and Black Seas (Grasshoff 1975, Yakushev et al. 2008) and the Cariaco Basin off the coast of Venezuela (Taylor et al. 2006), and are increasingly recognized as hot spots for prokaryotic activity. The steep physico-chemical gradients found in these transition zones are mirrored by different modes of microbial physiology, with prokaryotes playing important roles in biogeochemical processes such as chemoautotrophic production (Taylor et al. 2001, Jost et al. 2008), denitrification and ammonia oxidation (Hannig et al. 2007, Lam et al. 2007, Labrenz et al. 2010) and sulphur cycling (Jannasch et al. 1991, Jørgensen \& Bak 1991). Estimated growth rates for chemoautotrophic prokaryotes in these zones are substantial, with doubling times in the range of 1 to $2 \mathrm{~d}$ calculated for both the Cariaco Trench (Taylor et al. 2006) and the Baltic Sea (Jost et al. 2008). However, prokaryotic abundance tends to remain relatively constant, implying loss processes equivalent to new biomass production (Taylor et al. 2006). For oxic water masses, it is known that sedimentation is generally negligible (Güde 1986), but biological agents, such as protist grazing or viral lysis, can be major loss factors for prokaryotic production (Suttle 1994, Fuhrman 1999, Sherr \& Sherr 2002). However, to our knowledge, only 3 studies to date have experimentally measured (Detmer et al. 1993, Lin et al. 2007) or estimated (Setälä \& Kivi 2003) grazing rates on marine pelagic redoxcline prokaryotic communities, and only one has measured the impact of viruses (Weinbauer et al. 2003).

The existence of protist taxa occurring primarily or exclusively in suboxic or anoxic environments has long been known (Lauterborn 1901, Fenchel et al. 1977). Classic microscopy-based studies conducted both in marine and freshwater systems revealed an increased protist abundance at oxygen-hydrogen sulphide interfaces (Fenchel et al. 1990, Zubkov et al. 1992, Massana \& Pedrós-Alió 1994) and changes in the community composition throughout the redox gradient, with the appearance of different taxonomic groups compared to overlying oxygenated water masses (Zubkov et al. 1992, Fenchel et al. 1995).
Deeper anoxic zones were shown to harbour very low protist abundance, with many taxa forming symbiotic relationships with prokaryotes (Fenchel et al. 1977). The subsequent application of $18 \mathrm{~S}$ rRNA gene-based techniques revealed an unexpected richness of anaerobic protist communities, and uncovered the existence of novel, uncultivated taxa (e.g. Stoeck \& Epstein 2003, Behnke et al. 2006, Edgcomb et al. 2011). However, the functional role and impact of these protists on the prokaryotic communities remains largely unknown. Two of the existing studies assessing protist bacterivory at marine pelagic redoxclines, conducted in the Cariaco basin and the Baltic Sea, respectively, point towards a low grazing impact on the whole prokaryotic community (Setälä \& Kivi 2003, Lin et al. 2007). However, the third study, where a single measurement of grazing at one sulphidic depth in the Baltic Sea was carried out (Detmer et al. 1993), and results from grazing studies in freshwater and coastal saline lake redoxclines (e.g. Bettarel et al. 2004, Gobler et al. 2008, Saccà et al. 2009), indicate that the potential exists for a high bacterivorous pressure in these zones.

Viral lysis, the other major potential biological loss factor, is even more understudied for oxygendeficient systems. Existing estimates on mortality due to viruses in freshwater systems are scarce and variable, ranging from $<5$ to $50 \%$ of prokaryotic production, sometimes even within the same study (Bettarel et al. 2004). However, an increased importance of viral lysis in anoxic/sulphidic waters has been observed in several studies (Weinbauer \& Höfle 1998, Weinbauer et al. 2003). This, in combination with studies in other environments, such as hot springs (e.g. Breitbart et al. 2004), has led to the general hypothesis that in more extreme environments (with regard to abiotic factors such as oxygen or salinity), a shift in the major prokaryotic mortality factor from protist grazing to viral lysis occurs (Pedrós-Alió et al. 2000).

Here we focused on the Baltic Sea, one of the worlds' largest brackish environments. A stable halocline, situated at 60 to $80 \mathrm{~m}$ depth, limits vertical mixing and separates the water column into an upper oxygenated layer and a bottom oxygen-depleted layer which becomes anoxic and sulphidic in the deepest zones (Reissmann et al. 2009). The euphotic zone of the Baltic Sea proper extends only to 10 to $30 \mathrm{~m}$ depth (Sandén \& Håkansson 1996), with the deeper oxic-anoxic transition zones of the central basins therefore being located at aphotic depths. The highly active prokaryotic communities of Baltic Sea pelagic redoxclines have been well characterized 
(Grote et al. 2007, Labrenz et al. 2007, Glaubitz et al. 2009). However, scarce data exist on the composition of the protist communities and viral assemblages found there (e.g. Mamaeva 1988, Setälä 1991, Stock et al. 2009), or on their impact on prokaryotic communities (Setälä \& Kivi 2003, Weinbauer et al. 2003).

The aim of the present study was to (1) determine the bacterivorous impact of the protist community throughout the oxic-anoxic transition zone of 2 Baltic Sea basins with anoxic/sulphidic bottom waters (Landsort and Gotland Deep), (2) analyse the importance of different protist groups as bacterivores and (3) observe whether shifts occur along the oxygen gradient in the relative importance of protist grazing and viral lysis.

\section{MATERIALS AND METHODS}

\section{Study sites, sampling and measurement of physico-chemical parameters}

Sampling was conducted in the central Baltic Sea at Landsort Deep (Stn 284; 58 35.0' N, 18²14.0' E) and Gotland Deep (Stn 271; $57^{\circ} 19.2^{\prime} \mathrm{N}, 20^{\circ} 03^{\prime} \mathrm{E}$ ) on board the RV 'Maria S. Merian' in September 2009. Water was collected in $10 \mathrm{l}$ free-flow bottles attached to a conductivity, temperature and depth rosette (CTD) with a coupled oxygen sensor. Only the first 51 of each bottle were used for experimental purposes to avoid oxygen contamination during emptying of the free-flow bottles. Inorganic nutrients, oxygen and hydrogen sulphide were measured immediately on board according to standard methods (Grasshoff et al. 1983). Whole water column depth profiling was conducted at 10 to $50 \mathrm{~m}$ depth intervals from the surface to just above the sediments, and high-resolution redoxcline depth profiling was conducted at 2 to $5 \mathrm{~m}$ intervals around the chemocline.

\section{Determination of prokaryotic and viral abundance}

Total prokaryotic abundance was quantified by flow cytometry. Samples $(5 \mathrm{ml})$ were fixed immediately after retrieval with a mixture of paraformaldehyde and glutaraldehyde $(1 \%$ and $0.05 \%$ final concentration, respectively), flash-frozen in liquid nitrogen and stored at $-80^{\circ} \mathrm{C}$ until analysis. For viral counts, the same procedure was used, but employing glutaraldehyde $(0.5 \%$ final concentration; 2 to $4 \mathrm{ml}$ sample volume) as the fixative. Subsequently, thawed samples were stained with SYBR Green I (Invitro-
gen-Molecular Probes), and abundance was determined by flow cytometry. For prokaryotes, cell counts were determined on a FACScalibur (Becton Dickinson) flow cytometer as previously described (Gasol et al. 2004), and data analysis was conducted on Cell Quest Pro software (BD Biosciences). Virus abundance was determined on a FACSAria II (Becton Dickinson) flow cytometer as previously described (Brussaard 2004), and data analysis was performed using FACSDiva software (version 4.1; Becton Dickinson). Prokaryotic abundance is the result of single measurements, while viral abundance is given as the average of duplicate measurements.

\section{Determination of protist abundance}

For protists $<10 \mu \mathrm{m}$ in length (mainly HNF), $100 \mathrm{ml}$ samples were fixed immediately after retrieval in brown glass bottles with a final concentration of $1 \%$ particle free formaldehyde at $4^{\circ} \mathrm{C}$ for 2 to $24 \mathrm{~h}$. Subsamples were filtered onto black polycarbonate filters (Nuclepore, $0.8 \mu \mathrm{m}$ pore size, Whatman) and frozen until analysis. Upon thawing, filters were stained with DAPI (0.01 $\mathrm{mg} \mathrm{ml}^{-1}$ final concentration), and a minimum of 100 cells filter ${ }^{-1}$ were counted under an Axioskop 2 mot plus epifluorescence microscope using filter set 02 (Carl Zeiss MicroImaging).

For protists $>10 \mu \mathrm{m}$ in length (mainly ciliates and dinoflagellates), $200 \mathrm{ml}$ samples were fixed immediately after retrieval with acid Lugol's solution (Willen 1962; $1 \%$ final concentration) and stored in brown glass bottles at room temperature in the dark. Protists were later concentrated by sedimentation of the samples fixed with Lugol's solution in $100 \mathrm{ml}$ sedimentation chambers for a minimum of $24 \mathrm{~h}$ (Utermöhl 1958) and counted at a magnification of $200 \times$ under an Axiovert S100 inverted microscope (Carl Zeiss MicroImaging). Half or the whole counting chamber was enumerated, depending on protist abundance. Major ciliate groups were distinguished during counting based on morphological characteristics. However, due to the difficulty of proper taxonomic identification in samples fixed with Lugol's solution, these represent, in most cases, morphotypes resembling known groups or taxa and in the following will be abbreviated with 'cf.'. It should be noted that while fixative solutions and quantification methods were selected based on the available literature (reviewed by Sherr \& Sherr 1993), the concentration of Lugol's solution employed in this study could have led to an underestimation of the abundance of certain ciliates (Stoecker et al. 1994). 


\section{Measurement of protist bacterivory}

Protist bacterivory was measured for selected suboxic, oxygen-hydrogen sulphide interface and upper sulphidic depths at Landsort and Gotland Deep using an approach based on the disappearance of fluorescently labelled bacteria (FLB) during incubation (Marrasé et al. 1992). FLB were prepared before the cruise from Brevundimonas diminuta cultures as previously described (Vázquez-Domínguez et al. 1999). Sampling depths were determined based on oxygen and turbidity profiles recorded during a prior CTD cast. For the experimental set-up, acid-cleaned $500 \mathrm{ml}$ bottles with narrow necks were filled directly from the free-flow bottles upon arrival of the water on deck, with at least $30 \mathrm{~s}$ of overflow. FLB were then immediately added to a concentration of 10 to $20 \%$ of in situ prokaryotic abundance $(\sim 30 \mu \mathrm{l}$ of the FLB stock solution; in situ prokaryotic abundance was estimated from extensive existing data and later confirmed by flow cytometry in the laboratory), and the bottles were quickly closed with glass stoppers, avoiding any head space or air bubbles. Incubations were performed approximating in situ conditions $\left(4^{\circ} \mathrm{C}\right.$ and in the dark) for $24 \mathrm{~h}$. To avoid oxygen contamination during sub-sampling, separate sets of triplicate bottles were prepared for the 2 sampling points ( 0 and $24 \mathrm{~h}$ ). Controls were carried out to test for stability of added FLB under in situ physicochemical conditions and in the absence of grazers (removed by filtration through a $1 \mu \mathrm{m}$ pore sized filter; Nuclepore, Whatman) inside an anaerobic chamber (Coy Laboratories; forming gas atmosphere).

Fixation for protist and prokaryote samples, and protist quantification were carried out as described above. Prokaryote and FLB enumeration was conducted by epifluorescence microscopy. For this, subsamples were filtered onto black polycarbonate filters (Whatman; pore width, $0.2 \mu \mathrm{m}$ ) and stained with DAPI. Samples were then observed under a Zeiss Axioskop 2 mot plus microscope, and a minimum of 200 cells sample ${ }^{-1}$ or 50 fields were counted at a magnification of $1000 \times$ using filter set 02 for total prokaryotes and 09 for FLB (Carl Zeiss MicroImaging).

Protist grazing rates on the natural prokaryotic community were derived from the data following a previously described exponential model (Salat \& Marrasé 1994), with slight modifications to account for the fact that initial and final replicates stem from different incubation bottles. First, an average net prokaryotic growth (a) for the 3 replicates was obtained at each depth as:

$$
a=(1 / t) \times \ln \left(N_{t} / N_{0}\right)
$$

where $t$ is the incubation time, and $N_{0}$ and $N_{t}$ are the average initial and final prokaryotic abundance, respectively, for the 3 replicates at each depth.

Next, a specific grazing rate on FLB $(g)$ was obtained for each replicate at each depth as:

$$
g=-(1 / t) \times \ln \left(F_{t} / F_{0}\right)
$$

where $t$ is the incubation time, $F_{0}$ is the inoculated FLB abundance, and $F_{t}$ is the final FLB abundance measured for each replicate. The inoculated FLB abundance was obtained as the average FLB abundance for all initial replicates at all depths. This latter measure was possible since all flasks were inoculated with the same volume from the same FLB stock, resulting in the same average initial FLB abundance for all 3 depths (analysis of variance, ANOVA; $p>0.05$ ).

Since $a \neq 0$ (see Salat \& Marrasé 1994), the grazing rate on the natural prokaryotic community $(G)$ was obtained for each replicate at each depth as:

$$
G=(1 / t) \times(g / a) \times\left(N_{t}-N_{0}\right)
$$

For each replicate, the corresponding $g$ value for the replicate and the a value for that depth were used. $G$ values were then transformed into prokaryotes consumed $\mathrm{ml}^{-1} \mathrm{~d}^{-1}$, and the percentage of the prokaryotic standing stock grazed per day was calculated for each replicate at each depth.

As an alternative approach for estimating protist grazing impact, literature clearance rates were employed together with the protist abundance and biovolume data obtained throughout the redox gradient. Protist biovolumes were calculated using geometric models for representative cells of each distinguished morphotype divided into size groups with $10 \mu \mathrm{m}$ intervals. For HNF, a clearance rate of $5 \mathrm{nl} \mathrm{cell}{ }^{-1} \mathrm{~h}^{-1}$, determined for HNF in Baltic Sea surface waters (Kuuppo-Leinikki 1990), was applied to the abundance at each depth. For dinoflagellates, a rate of $2.2 \times 10^{4}$ body volumes $\mathrm{h}^{-1}$ (Neuer \& Cowles 1995) was applied to dinoflagellate cell volume data. The equation does not take shrinkage due to fixation into account, but estimated clearance rates fell within values previously determined for dinoflagellates of similar size (e.g. Strom 1991). For ciliates, a biovolumedependent equation to determine clearance rates $(y)$, established for Baltic Sea ciliates (Setälä \& Kivi 2003), was applied:

$$
y=0.1493 x^{0.906}
$$

where $x$ is the equivalent spherical diameter of the ciliate. The equation takes into account cell shrinkage due to fixation. 


\section{Examination of protist food vacuole contents}

The bacterivorous potential of different protist groups was qualitatively assessed through the observation of presence/absence of FLB inside food vacuoles at the end of the grazing experiments, and through catalyzed reporter deposition-fluorescence in situ hybridization (CARD-FISH), applied to filters obtained from different depths throughout the redoxcline and targeting prokaryotes inside food vacuoles. FLB detection was carried out using the microscopy samples employed for the quantification of HNF (0.8 $\mu$ m filters as described above; filter set 09 for detection, Carl Zeiss MicroImaging). Samples for CARD-FISH $(200 \mathrm{ml})$ were obtained in parallel to the microbial profile sampling and fixed immediately after retrieval with the alkaline Lugol's solution-formalin-thiosulphate method (Sherr \& Sherr 1993, Medina-Sánchez et al. 2005). The complete volume was filtered onto polycarbonate filters (Nuclepore, pore size $2.0 \mu \mathrm{m}, 47 \mathrm{~mm}$ diameter, Whatman) which were subsequently frozen. CARDFISH was carried out on thawed filters employing a modified version of an established protocol (Medina-Sánchez et al. 2005), which excluded the permeabilization step with achromopeptidase since it severely damaged the protist cell integrity in our samples. Bacteria were detected using probes EUB 338 I, II and III (1:1:1 mix; Daims et al. 1999), and Crenarchaeota with probe Cren537 (Teira et al. 2004). We targeted Crenarchaeota since they are dominant constituents of the redoxcline prokaryotic communities in central Baltic Sea suboxic zones, constituting up to $25 \%$ of total cell counts (Labrenz et al. 2010).

\section{Estimation of the frequency of virally infected prokaryotic cells (FIC)}

FIC was determined for different depths throughout the redoxcline using a virus dilution approach (Wilhelm et al. 2002). Specifically, water samples (2 l) were filtered (Isopore, pore size $3 \mu \mathrm{m}, 47 \mathrm{~mm}$ diameter, Millipore) to remove larger planktonic organisms. The prokaryotes contained in the filtrate were then concentrated (45 to $60 \mathrm{ml}$ final volume) using a tangential-flow filtration device with a pore size of $0.22 \mu \mathrm{m}$ (Vivaflow 200, polyethersulphone, Sartorius Stedim). The viruses contained in this second filtrate were subsequently removed using a tangential-flow filtration device with a molecular weight cut-off of 100 kDa (Vivaflow 200, polyethersulphone, Sartorius
Stedim) yielding virus-free water. In order to estimate FIC due to lytic viruses, duplicate aliquots of the prokaryotic concentrate $(10$ to $15 \mathrm{ml})$ were dispensed into tightly sealable polypropylene tubes and filled-up to a total volume of $50 \mathrm{ml}$ with virus-free water from the same station and depth. FIC due to lysogenic viruses was determined by inducing them in a second set of duplicate experiments through the addition of Mitomycin C (1 $\mu \mathrm{g} \mathrm{ml}^{-1}$ final concentration; Sigma Aldrich). Incubations were performed in the dark at $18^{\circ} \mathrm{C}$ for up to $30 \mathrm{~h}$, and subsamples to determine prokaryotic and viral abundance were taken every 4 to $5 \mathrm{~h}$.

Samples for virus abundance were fixed and enumerated as described above. Samples for prokaryote abundance were fixed with glutaraldehyde $(0.5 \%$ final concentration) and quantified on a FACSAria II (Becton Dickinson) flow cytometer as previously described (Marie et al. 1999). FIC due to lytic viruses was calculated based on the increase in viral abundance in the unamended incubations, assuming a burst size of 30 viruses per lysed prokaryotic cell for suboxic waters and 90 for oxygen-hydrogen sulphide interface and anoxic waters (Weinbauer et al. 2003, Winter et al. 2004). FIC due to lysogenic viruses was calculated as the difference between the results from Mitomycin C-amended and unamended incubations (Weinbauer et al. 2003). Detection of FIC due to lysogeny was only considered significant when results for Mytomycin C treatments were higher than results from unamended incubations (taking the variation of the duplicate estimates into account).

\section{RESULTS}

\section{Study site physico-chemical characteristics and microbial abundance}

Both Landsort and Gotland Deep had clearly stratified water columns with anoxic/sulphidic bottom waters (Fig. 1). Prokaryote abundance was highest in surface waters and decreased strongly below 25 to $50 \mathrm{~m}$ depth (Fig. 1), with cell counts at the redoxcline ranging from $5 \times 10^{5}$ to $14 \times 10^{5}$ cells ml ${ }^{-1}$ (Figs. $1 \&$ 2 ). Protists were only quantified for the high-resolution redoxcline profiles (Fig. 2). HNF showed a maximum abundance at the oxygen-hydrogen sulphide interface, but always remained below 800 cells ml $^{-1}$ (Fig. 2). The community was represented equally in terms of abundance by larger (3 to $6 \mu \mathrm{m}$ length) and smaller (1.5 to $3 \mu \mathrm{m}$ ) HNF (data not shown). Dinofla- 


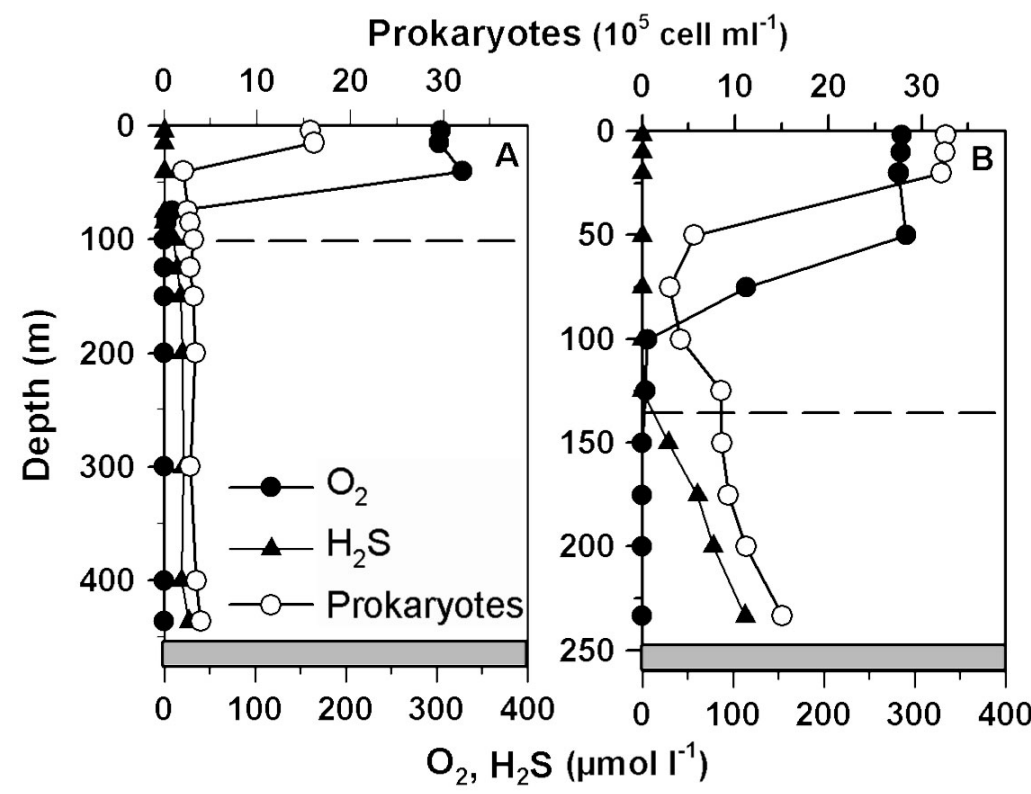

Fig. 1. Whole water column vertical profiles for oxygen, hydrogen sulphide and prokaryote concentrations taken at (A) Landsort Deep and (B) Gotland Deep. The dashed line indicates the chemocline, or zone of first hydrogen sulphide appearance, and the shaded area represents the sediment

gellates showed high abundances in the suboxic zone (Fig. 2), and mainly consisted of rounded morphotypes with a diameter of 15 to $30 \mu \mathrm{m}$ (major axis; data not shown). When observed through epifluoresence microscopy, no autofluorescence could be observed, suggesting a heterotrophic lifestyle for HNF and dinoflagellates.

Ciliates reached their maximum abundance just above the chemocline (9 to 13 cells $\mathrm{ml}^{-1}$ ) and showed clear changes in morphotype composition throughout the oxygen gradient in both study sites (Fig. 2). Cf. Strombidium (20 to $30 \mu \mathrm{m}$ length) dominated the suboxic zone, with abundances up to 7 cells ml ${ }^{-1}$ in Landsort Deep and 2.7 cells ml ${ }^{-1}$ in Gotland Deep. At very low oxygen concentrations $\left(<5 \mu \mathrm{mol} \mathrm{\textrm {l } ^ { - 1 }}\right)$, before hydrogen sulphide levels increased, the community was dominated by Metacystis spp. (present as several different morphotypes, ranging from 20 to $150 \mu \mathrm{m}$ in length), cf. Mesodinium and cf. Coleps. Finally, in waters with increasing hydrogen sulphide concentrations, protist abundance strongly decreased (1 to 3 cells $\mathrm{ml}^{-1}$ ), and the protist community became numerically dominated by unidentified ciliates at Landsort Deep and Metacystis spp. at Gotland Deep.

\section{Impact of protist grazing on redoxcline prokaryotic communities}

FLB experiments were carried out at Landsort and Gotland Deep with water collected at suboxic, oxygen-hydrogen sulphide interface and sulphidic depths (Table 1). The protist communities observed in the incubations resembled those seen in the profiles for zones of similar physico-chemical characteristics (Fig. 2; and observations from previous years, R. Anderson \& F. Weber unpubl. data), with the exception of suboxic waters at Gotland Deep, where Metacystis spp. were also detected (data not shown). No significant changes in protist abundance occurred during the incubations, except at the sulphidic depth at Gotland Deep, where a $50 \%$ reduction in protist numbers was observed (Student's $t, \mathrm{p}<0.05)$, mainly due to a decrease in Metacystis spp. abundance.

FLB quantification revealed significant differences between the initial and final cell counts at the oxygen-hydrogen sulphide interface of both study sites and the suboxic depth of Landsort Deep (Table 2; ANOVA, $p<0.05$ ). In all 3 cases, calculated grazing rates were high, resulting in the removal of an average 50 to $80 \%$ of the prokaryotic standing stock per day. For the other 3 depths, the decrease in FLB abundance was not significant due to small changes in cell counts (suboxic and sulphidic waters at Gotland Deep) or a high variability between replicates at the final time point (sulphidic waters at Landsort Deep). Control treatments showed no significant differences between initial and final FLB abundance. Net positive growth of the natural prokaryotic community during experimental incubations was only observed for sulphidic depths (Table 2). In suboxic and oxygen-hydrogen sulphide interface waters, growth rates were negative, indicating a decrease in prokaryotic abundance over time, or were close to zero.

Estimated grazing rates based on literature clearance rates for the different protist groups and in situ protist abundances supported the measured grazing rates (Fig. 2). At suboxic depths, estimated rates ranged between 30 and $>100 \% \mathrm{~d}^{-1}$ of bacterial standing stocks and were dominated by dinoflagellates and ciliates, while at the oxygen-hydrogen sulphide interface, grazing rates ranged between 30 


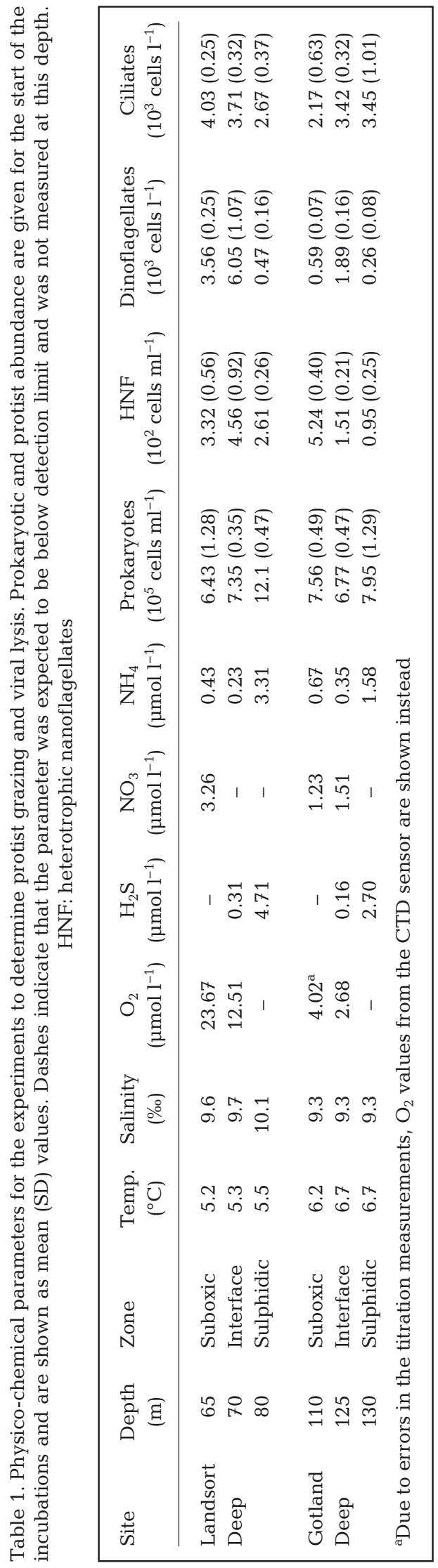

the redoxcline (Table 3). For ciliates and dinoflagellates, not enough cells could be detected to obtain accurate percentages of cells containing FLB or cells labelled through CARD-FISH, but a qualitative assessment could be made. In this sense, cf. Strombidium and large unidentified ciliates (150 to $350 \mu \mathrm{m}$ long) detected at the oxygen-hydrogen sulphide interface and sulphidic waters always contained large numbers of FLB or Bacteria and Crenarchaeota in their food vacuoles. Dinoflagellates generally contained Bacteria and Crenarchaeota (FLB detection was not possible due to rapid fading of the fluorochrome signal and strong DAPI signal from the dinoflagellates). Finally, cf. Coleps and Metacystis spp. contained FLB or Bacteria and Crenarchaeota less often in their food vacuoles, and none were ever detected inside cf. Mesodinium. However, in this last case, cells always contained large quantities of autofluorescent pigments which could have masked the fluorescence of ingested, labelled cells. Additionally, large numbers of potentially symbiotic Bacteria and Crenarchaeota were detected in most ciliates on the surface and/or in the cytoplasm at the oxygenhydrogen sulphide interface and in sulphidic waters.

\section{Viral abundance and impact on the prokaryotic communities}

Viral counts were highest in surface waters (Fig. 3), coinciding with the maxima in prokaryotic abundance (Fig. 1) and then decreased down to around $50 \mathrm{~m}$ depth, thereafter remaining relatively constant. However, no significant correlations were observed at Gotland Deep between prokaryotic and viral abundance, and only a weak positive correlation was observed at Landsort Deep $(r=$ 0.410 ; Kendall's tau $\mathrm{p}<0.01$ ). High-resolution profiles of the redoxcline showed no marked changes in total viral abundance (Fig. 3), and again no significant correlations were observed with prokaryotic abundance. Virus to prokaryote ratios (VPRs) ranged from 10 to 60 throughout the whole water column, with highest values above the redoxcline. At the redoxcline itself, VPRs remained relatively constant (15 to 30).

The dilution experiments conducted in parallel to the grazing studies only detected infection by lytic viruses. FIC was highest at suboxic depths (average of $19 \%$ in Landsort and $6 \%$ in Gotland Deep) and then decreased to $2-3 \%$ in oxygen-hydrogen sulphide interface and anoxic depths at both study sites (Table 2). Additional dilution experiments to deter- 
Table 2. Protist grazing rates, frequency of virally infected cells (FIC) and prokaryotic growth rates measured at Gotland and Landsort Deep. Grazing rates are given as the mean (SD) of triplicate measurements, while FIC is the mean (range) of duplicate measurements. Asterisks indicate significant differences between initial and final fluorescently labelled bacteria (FLB) counts $(t$-test, $\mathrm{p}<0.05)$

\begin{tabular}{|c|c|c|c|c|c|c|}
\hline Site & $\begin{array}{l}\text { Depth } \\
\text { (m) }\end{array}$ & Zone & $\begin{array}{l}\text { Net prokaryotic } \\
\text { growth rate }\left(\mathrm{d}^{-1}\right)\end{array}$ & $\begin{array}{c}\text { Grazing rate } \\
\left(10^{5} \text { prokaryotes } \mathrm{ml}^{-1} \mathrm{~d}^{-1}\right)\end{array}$ & $\begin{array}{l}\text { Prokaryotic standing } \\
\text { stock grazed }\left(\% \mathrm{~d}^{-1}\right)\end{array}$ & FIC (\%) \\
\hline Landsort & 65 & Suboxic & -0.23 & $5.19(1.82)^{*}$ & $80.8(28.3)$ & $19(13-25)$ \\
\hline \multirow[t]{2}{*}{ Deep } & 70 & Interface & -0.18 & $3.79(0.80)^{*}$ & $51.5(10.9)$ & $3(1.5-4)$ \\
\hline & 80 & Sulphidic & 0.14 & 4.58 (3.61) & $38.0(22.0)$ & $2(1.5-2.5)$ \\
\hline Gotland & 110 & Suboxic & 0.01 & $1.92(1.66)$ & $25.4(22.0)$ & $6(5-7)$ \\
\hline \multirow[t]{2}{*}{ Deep } & 125 & Interface & -0.19 & $3.32(0.75)^{*}$ & $49.0(11.1)$ & $2(1.5-2.5)$ \\
\hline & 130 & Sulphidic & 0.31 & 1.15 & $14.0(18.2)$ & $3(2.5-3.5)$ \\
\hline
\end{tabular}

Table 3. Percentage of heterotrophic nanoflagellates (HNF) containing fluorescently labelled bacteria (FLB) or prokaryotes hybridized with Bacteria- or Crenarcheota-specific CARD-FISH probes (EUB and Cren, respectively). The total number of HNF cells analysed (n) is shown in parentheses

\begin{tabular}{|c|c|c|c|c|c|c|c|c|}
\hline \multirow[t]{2}{*}{ Sampling } & \multicolumn{4}{|c|}{ Landsort Deep } & \multirow[b]{2}{*}{ Depth (m) } & \multicolumn{2}{|c|}{ - Gotland Deep - } & \multirow[b]{2}{*}{ + Cren } \\
\hline & Depth (m) & + FLB & + EUB & + Cren & & + FLB & + EUB & \\
\hline \multicolumn{9}{|l|}{ Profile } \\
\hline & 75 & - & $63.7(80)$ & $57.5(80)$ & 100 & - & $39.2(79)$ & $38.8(80)$ \\
\hline & 80 & - & $58.7(80)$ & $41.2(80)$ & 117.5 & - & $37.3(75)$ & $30.3(67)$ \\
\hline & 87.5 & - & $56.2(80)$ & $38.7(80)$ & 125 & - & $52.5(80)$ & $45.0(80)$ \\
\hline & 120 & - & $57.5(40)$ & $21.9(41)$ & 132.5 & - & $45.0(60)$ & $32.2(62)$ \\
\hline \multicolumn{9}{|c|}{ FLB experiment } \\
\hline & 65 & $48.2(83)$ & - & - & 100 & $53.0(83)$ & - & - \\
\hline & 70 & $46.2(80)$ & - & - & 125 & $55.0(80)$ & - & - \\
\hline & 80 & $22.9(61)$ & - & - & 130 & $35.5(76)$ & - & - \\
\hline
\end{tabular}

mine FIC at other depths throughout the redoxcline showed similar results to those conducted in parallel to the grazing experiments (Fig. 3). Lysogenic viral infection was constantly below the detection limit, and the frequency of virally infected cells was highest in suboxic zones (10 to $20 \%$ ), and then decreased to $<5 \%$ at interface and anoxic depths.

\section{DISCUSSION}

\section{Study site physico-chemical and microbial characteristics}

Physico-chemical parameters obtained at both study sites showed clearly stratified water columns with anoxic bottom waters (Fig. 1). Both the physicochemical characteristics and prokaryotic cell counts were in accordance with previous observations from Baltic Sea redoxclines (e.g. Jost et al. 2008). However, it should be noted that in Baltic Sea redoxclines lateral intrusion of different water masses and small- scale mixing events occur (Lass et al. 2003), which can produce physico-chemical conditions not normally found at the sampling sites and might affect microbial assemblages. Likely examples of this phenomenon were found at 105 and $110 \mathrm{~m}$ depth in the Gotland Deep profiles (Fig. 2) and the suboxic depth selected for the FLB experiment at Gotland Deep (110 m; Tables 1 \& 2), all of which presented anomalous physico-chemical and microbial characteristics. Data from these specific anomalous depths will not be considered further here.

To our knowledge, this study represents the first high-resolution analysis on the distribution of different broad protist groups ( $\mathrm{HNF}$, dinoflagellates and ciliates) along the physico-chemical gradient of Baltic Sea redoxclines. Some previous studies assessed the protist community at Gotland Deep, but these were mainly restricted to a few depths and centred on the phylogenetic or morphospecies composition (e.g. Mamaeva 1988, Setälä 1991, Stock et al. 2009). Our results show clear patterns in the distribution and composition of the protist community 


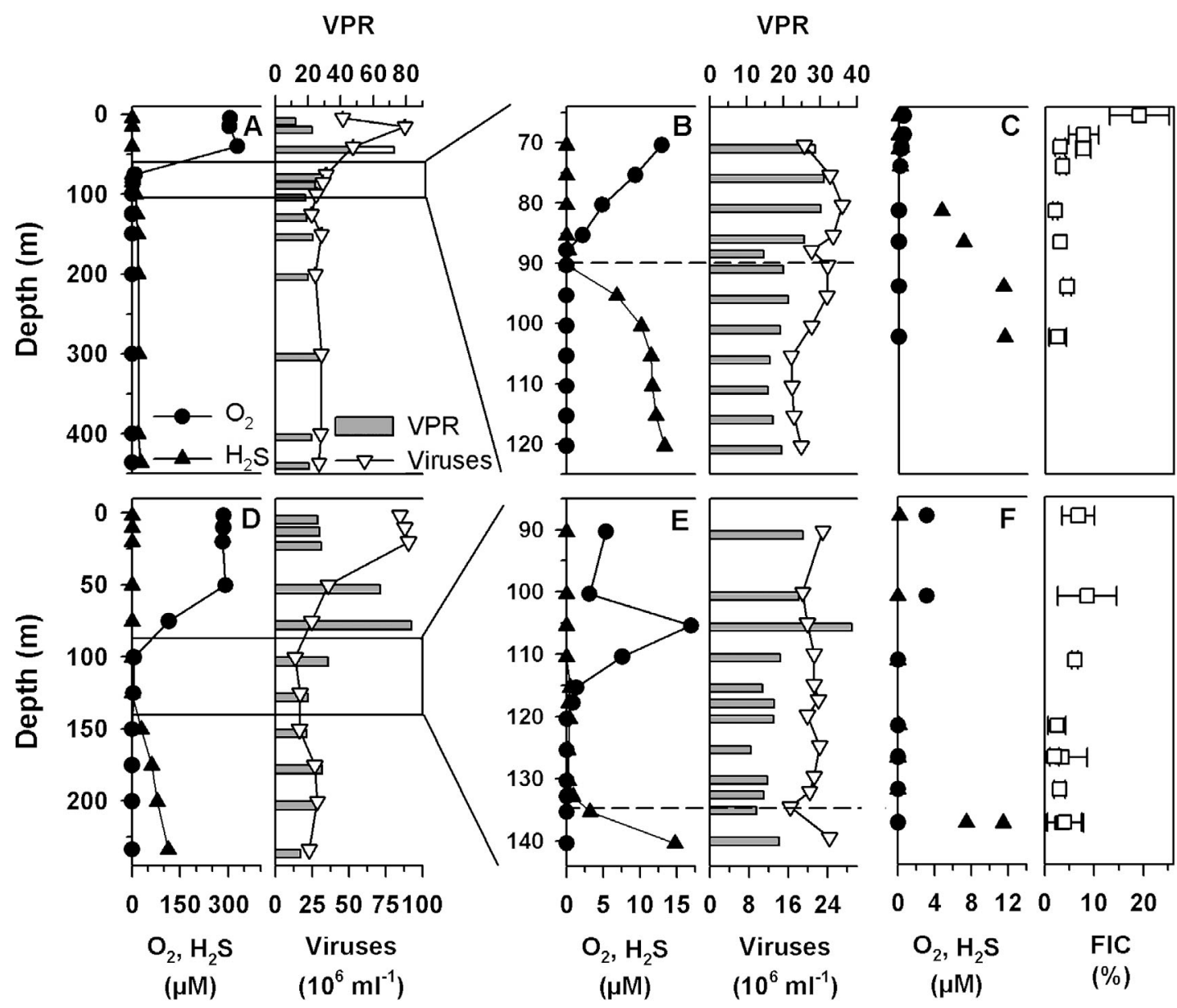

Fig. 3. Viral abundance and virus to prokaryote ratio (VPR), shown with the corresponding oxygen and hydrogen sulphide values for each depth, for $(A, D)$ the whole water column and $(B, E)$ the redoxcline at high resolution at $(A-C)$ Landsort Deep and (D-F) Gotland Deep. (C, F) For the redoxcline, average frequencies of infected cells (FIC) were determined on different casts (error bars represent the range), and are shown with the corresponding oxygen and hydrogen sulphide values for that depth

along the redox gradient, similar to previous observations from Baltic Sea redoxclines (R. Anderson \& F. Weber unpubl. data) and from other suboxic to anoxic marine and brackish systems (e.g. Zubkov et al. 1992, Fenchel et al. 1995). Three zones could be distinguished with regard to the protist community composition: (1) suboxic: dominated by Strombidium-like small ciliates and dinoflagellates; (2) oxygen-hydrogen sulphide interface: dominated by Metacystis spp., cf. Mesodinium and cf. Coleps; and (3) upper anoxic/sulphidic, with very low protist counts and dominated by Metacystis spp. and/or unidentified ciliates. HNF showed highest abundances at the oxygen-hydrogen sulphide interface, but were always present at low abundances (100 to 800 cells ml ${ }^{-1}$ ), an order of magnitude lower than in Baltic Sea surface waters (Kuuppo-Leinikki 1990, Piwosz \& Pernthaler 2010).

\section{Protist grazing impact}

The observed shifts in protist community composition were accompanied by changes in the estimated and the measured grazing rates on the prokaryotic community (Fig. 2, Table 2). The FLB experiments revealed significant and high grazing at the suboxic depth of Landsort Deep and at the oxygen-hydrogen sulphide interface of both study sites, accounting for respectively $\sim 80 \pm 30 \%$ and $50 \pm 10 \%$ of prokaryotic standing stock per day (Table 2 ). These results were consistent with the estimated shifts in grazing pressure based on protist abundance and biovolume, which showed daily grazing rates ranging from 30 to $>100 \%$ of prokaryotic standing stock in the suboxic zone, and from 30 to $90 \%$ at the oxygen-hydrogen sulphide interface (Fig. 2). These bacterivory rates are considerably higher than those 
estimated in a previous study at the Gotland Deep, which used the same biovolume-dependent theoretical clearance rates as in the present study but found lower ciliate abundances $\left(<10^{3}\right.$ ciliates $\mathrm{l}^{-1}$; Setälä \& Kivi 2003). However, it should be noted that Setälä \& Kivi (2003) only employed data from 4 suboxic to anoxic depths, and protist abundance tends to shift strongly within a short vertical distance in the Baltic Sea redox gradient (Fig. 2 \& observations from previous years: R. Anderson \& F. Weber unpubl. data). Therefore, zones of high protist abundance and grazing impact could have been missed in the study by Setälä \& Kivi (2003).

Overall, the good agreement between the estimated and measured grazing rates indicates that they are within reasonable ranges for the in situ protist community found at the 2 study sites. This indicates moreover that the results obtained do not seem to have been significantly biased by the method employed, e.g. through selection for or against FLB, a known problem associated with this technique (Landry et al. 1991, Mischke 1994), or incubationrelated biases, such as changes in protist activity during the incubation. Thus, we conclude that protist grazing can constitute a major mortality factor for suboxic and oxygen-hydrogen sulphide interface prokaryotic communities in Baltic Sea redoxclines, similar to what has been seen for certain seasonally hypoxic lakes (e.g. Bettarel et al. 2004, Gobler et al. 2008 ) and shallow oxygen minimum zones (Cuevas \& Morales 2006).

At upper sulphidic depths, estimated grazing rates were very low and measured rates were low and variable, with no statistical significance, and therefore below the detection limit of our methodology. These results are in accordance with the low protist abundance found at sulphidic depths of Baltic Sea redoxclines in this and previous studies (Mamaeva 1988, Setälä 1991, Detmer et al. 1993), indicating that the sulphidic zone could generally be a zone of reduced protist grazing pressure. Detmer et al. (1993) measured high protist bacterivory at one deeper sulphidic depth (gross prokaryotic production: $48 \%$ $\mathrm{d}^{-1}$ ). However, the filtration procedure they employed to obtain water for the dilution approach likely altered the physico-chemical conditions of the water (e.g. loss of hydrogen sulphide) and could have thus from the start considerably altered growth conditions for the prokaryotic community. Grazing estimates from other sulphidic systems are scarce and show a high variability. In euphotic sulphidic water masses, estimated grazing impacts range from very low (e.g. Massana \& Pedrós-Alió 1994) to an estimated $72 \%$ of gross growth per day (Saccà et al. 2009). In the only other aphotic sulphidic water mass studied, the Cariaco Basin, little impact of grazing on the total prokaryotic abundance was observed, but shifts in major phylogenetic groups could be detected upon removal of grazers, indicative of selective grazing (Lin et al. 2007). This may also have occurred in our study. However, it should be noted that Lin et al. (2007) found high HNF abundances (1.5 to $3 \times$ $10^{3} \mathrm{cells} \mathrm{ml}^{-1}$; ciliate and dinoflagellate data were not available), which could have exerted a significant, potentially selective (Jürgens \& Matz 2002) grazing pressure. In the present study, HNF abundance was

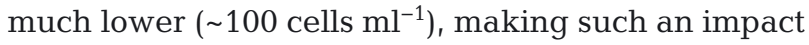
unlikely.

In addition to the above assessments, the bacterivorous role of different protist groups in Baltic Sea redoxclines was analysed through the examination of food vacuole content and theoretical considerations. The analysis of food vacuole content revealed that nearly all observed protists had the potential for bacterivory, although some of the larger ciliates (e.g. Coleps cf.) contained prokaryotes less often, potentially indicating a more predatorial role on smaller protists (e.g. observed FLB could belong to the food vacuoles of protist prey). For HNF, the consistency of the percentage of flagellates containing FLB or Bacteria detected by CARD-FISH indicates that around $50 \%$ of HNF were active grazers at most depths (Table 3). However, their low abundance excludes them from being major predators (Fig. 2). Thus, as opposed to surface waters where grazing is dominated by small bacterivorous flagellates (Sherr \& Sherr 2002, Jürgens \& Massana 2008), ciliates and, under suboxic conditions also dinoflagellates, would constitute the major grazers of Baltic Sea oxic-anoxic transition zones.

\section{Relative importance of protist grazing and viral prokaryotic mortality}

The analysis of the frequency of virally infected prokaryotic cells showed that lysogeny remained below detection throughout the redoxcline. Lytic infection was highest in the suboxic zone (up to $25 \%$ of prokaryotic abundance), and decreased to $<5 \%$ at the oxygen-hydrogen sulphide interface and in sulphidic zones (Fig. 3). Thus, viral lysis did not appear to constitute a major prokaryotic mortality factor at the water depths examined. The rationale behind the virus dilution approach (Wilhelm et al. 2002) is to dramatically reduce viruses and therefore prevent new 
viral infections during the incubation. Thus, an increase in viruses is only due to viral infections which had already occurred in the source water prior to the start of the incubation and is not an artefact of the incubation itself. However, this methodology requires the water to be filtered, and, for redoxcline samples, every filtration alters the in situ physicochemical conditions (e.g. oxygen or hydrogen sulphide concentrations). Thus, FIC estimates may have suffered from this disturbance. However, prokaryotic abundance in the incubations was stable over time, exhibiting no drastic decreases in abundance such as would occur through a strong toxic effect of oxygen. Additionally, FIC from suboxic and oxygen-hydrogen sulphide interfaces should be less impacted than for sulphidic depths.

A previous study conducted at Gotland Deep (Weinbauer et al. 2003) detected similar or slightly higher FIC for suboxic zones, but also found increased FIC (up to $25 \%$ of prokaryotic abundance) in the anoxic/sulphidic zone. Weinbauer et al. (2003) did not reduce viral abundances through dilution, which excludes the problem of oxygen contamination. However, new viral infection during their particularly long incubation times of up to $3 \mathrm{~d}$ may have increased their estimates in all zones. This is especially important in the Mitomycin C-induced treatments used to determine the impact of lysogenic viruses. Mitomycin C causes DNA damage affecting DNA replication and cell division, resulting in greatly elongated cells. Because viral contact rates increase with the size of host cells (Murray \& Jackson 1992), estimates of FIC due to lysogenic viruses by Weinbauer et al. (2003) may be higher than in situ.

Overall, prokaryotic mortality decreased from suboxic to upper anoxic/sulphidic depths, with the reduction in bacterivorous pressure not being accompanied in the depths analysed by a corresponding increase in viral to prokaryote ratios or FIC. This could also be observed in the net prokaryotic growth rates, which were negative or close to 0 in suboxic and oxygen-hydrogen sulphide interface waters, but positive for upper sulphidic zones (Table 2).

Baltic Sea upper sulphidic layers have been shown to exhibit high chemoautotrophic productivity (Jost et al. 2010), but no observable increases in prokaryotic abundance occur compared to overlying suboxic and oxygen-hydrogen sulphide interface depths (Figs. 1 \& 2) (Grote et al. 2007, Labrenz et al. 2007). However, neither protist grazing nor viral lysis appeared to be major prokaryotic mortality factors in this zone. A similar phenomenon has been observed for some stratified lakes where summed mortality in the metalimnion and seasonally in the hypolimnion remained below $50 \%$ of prokaryotic production (Bettarel et al. 2004). This observed discrepancy between prokaryotic production and mortality rates in upper sulphidic zones is a major open question requiring further study. Potential biases in the measurement of productivity and mortality should be determined, along with the assessment of other potential mortality factors (i.e. physical, e.g. sedimentation, or biological, e.g. apoptotis, processes). A significantly higher grazing impact than measured here is unlikely at these depths, due to the very low protist abundance (Fig. 2), but viral lysis could have been underestimated (as discussed above). Additionally, it should be considered that for some prokaryotic groups, specific mortality by selective protist grazing or viral infection might result in significantly higher losses than averaged for the total prokaryotic community.

\section{CONCLUSIONS}

In the present study, we showed a clear and consistent shift along 2 Baltic Sea redox gradients in both the protist community composition and the grazing pressure exerted on the prokaryotic community. Protist bacterivory dominated prokaryotic mortality at suboxic and oxygen-hydrogen sulphide interface depths, but decreased strongly in sulphidic zones. In contrast, viruses did not appear to constitute a strong loss factor for prokaryotic communities at either study site. Thus, for upper sulphidic depths there is a discrepancy between the high prokaryotic productivity previously measured for these zones and a low estimated mortality. Finally, we uncovered differences in the redoxcline food web structure when compared to surface waters, with HNF playing only a marginal role, and ciliates and dinoflagellates acting as the major bacterivores.

Acknowledgements. This study was supported by grant JU376/11-1 from the German Science Foundation (DFG), the Leibniz Institute for Baltic Sea Research and the Programme for the Formation of Researchers from the Department of Education, Universities and Research of the Basque Government (grant issued to R.A.). We thank A. Hagenmeier for chemical field work; A. Grüttmüller for technical assistance with flow cytometry; S. Busch, R. Hansen, S. Agatha and P. Quintana-Alonso for help in the identification of protist morphotypes; and G. Jost, M. Labrenz, C. Wylezich, F. Weber, D. Bombar, J. Feike, K. Becker and B. Buuk for assistance, comments and advice. We are also very grateful to the captain and crew of the RV 'Maria. S. Merian' for their support during the cruises. 


\section{LITERATURE CITED}

Behnke A, Bunge J, Barger K, Breiner HW, Alla V, Stoeck T (2006) Microeukaryote community patterns along an $\mathrm{O}_{2} / \mathrm{H}_{2} \mathrm{~S}$ gradient in a supersulfidic anoxic fjord (Framvaren, Norway). Appl Environ Microbiol 72:3626-3636

> Bettarel Y, Sime-Ngando T, Amblard C, Dolan J (2004) Viral activity in two contrasting lake ecosystems. Appl Environ Microbiol 70:2941-2951

Breitbart M, Wegley L, Leeds S, Schoenfeld T, Rohwer F (2004) Phage community dynamics in hot springs. Appl Environ Microbiol 70:1633-1640

Brussaard CPD (2004) Optimization of procedures for counting viruses by flow cytometry. Appl Environ Microbiol 70:1506-1513

> Cuevas LA, Morales CE (2006) Nanoheterotroph grazing on bacteria and cyanobacteria in oxic and suboxic waters in coastal upwelling areas off northern Chile. J Plankton Res 28:385-397

Daims H, Bruhl A, Amann R, Schleifer KH, Wagner M (1999) The domain-specific probe EUB338 is insufficient for the detection of all Bacteria: development and evaluation of a more comprehensive probe set. Syst Appl Microbiol 22:434-444

> Detmer AE, Giesenhagen HC, Trenkel VM, Auf Dem Venne H, Jochem FJ (1993) Phototrophic and heterotrophic pico- and nanoplankton in anoxic depths of the central Baltic Sea. Mar Ecol Prog Ser 99:197-203

Edgcomb V, Orsi W, Taylor GT, Vdacny P, Taylor C, Suarez P, Epstein S (2011) Assessing marine protists from the anoxic Cariaco Basin. ISME J 5:1237-1241

$>$ Fenchel T, Perry T, Thane A (1977) Anaerobiosis and symbiosis with bacteria in free-living ciliates. J Protozool 24: 154-163

Fenchel T, Kristensen LD, Rasmussen L (1990) Water column anoxia: vertical zonation of planktonic protozoa. Mar Ecol Prog Ser 62:1-10

Fenchel T, Bernard C, Esteban G, Finlay BJ, Hansen PJ, Iversen N (1995) Microbial diversity and activity in a Danish fjord with anoxic deep water. Ophelia 43:45-100

Fuhrman JA (1999) Marine viruses and their biogeochemical and ecological effects. Nature 399:541-548

> Gasol JM, Casamayor EO, Joint I, Garde K and others (2004) Control of heterotrophic prokaryotic abundance and growth rate in hypersaline planktonic environments. Aquat Microb Ecol 34:193-206

Glaubitz S, Lueders T, Abraham WR, Jost G, Jürgens K, Labrenz $M(2009){ }^{13} \mathrm{C}$-isotope analyses reveal that chemolithoautotrophic Gamma- and Epsilonproteobacteria feed a microbial food web in a pelagic redoxcline of the central Baltic Sea. Environ Microbiol 11:326-337

Gobler CJ, Davis TW, Deonarine SN, Saxton MA, Lavrentyev PJ, Jochem FJ, Wilhelm SW (2008) Grazing and virus-induced mortality of microbial populations before and during the onset of annual hypoxia in Lake Erie. Aquat Microb Ecol 51:117-128

Grasshoff K (1975) The hydrochemistry of landlocked basins and fjords. Academic Press, London

Grasshoff K, Erhardt M, Kremling K (1983) Methods of seawater analysis. Verlag Chemie, Weinheim

Grote J, Labrenz M, Pfeiffer B, Jost G, Jürgens K (2007) Quantitative distributions of Epsilonproteobacteria and a Sulfurimonas subgroup in pelagic redoxclines of the Central Baltic Sea. Appl Environ Microbiol 73:7155-7161

Güde H (1986) Loss processes influencing growth of planktonic bacterial populations in Lake Constance. J Plankton Res 8:795-810
Hannig M, Lavik G, Kuypers MMM, Woebken D, MartensHabbena W, Jürgens K (2007) Shift from denitrification to anammox after inflow events in the central Baltic Sea. Limnol Oceanogr 52:1336-1345

Jannasch HW, Wirsen CO, Molyneaux SJ (1991) Chemoautotrophic sulfur-oxidizing bacteria from the Black Sea. Deep-Sea Res 38:S1105-S1120

Jørgensen BB, Bak F (1991) Pathways and microbiology of thiosulfate transformations and sulfate reduction in a marine sediment (Kattegat, Denmark). Appl Environ Microbiol 57:847-856

Jost G, Zubkov MV, Yakushev E, Labrenz M, Jürgens K (2008) High abundance and dark $\mathrm{CO}_{2}$ fixation of chemolithoautotrophic prokaryotes in anoxic waters of the Baltic Sea. Limnol Oceanogr 53:14-22

> Jost G, Martens-Habbena W, Pollehne F, Schnetger B, Labrenz M (2010) Anaerobic sulfur oxidation in the absence of nitrate dominates microbial chemoautotrophy beneath the pelagic chemocline of the eastern Gotland Basin, Baltic Sea. FEMS Microbiol Ecol 71:226-236

Jürgens K, Massana R (2008) Protistan grazing on marine bacterioplankton. In: Kirchman DL (ed) Microbial ecology of the oceans. John Wiley \& Sons, Hoboken, NJ, p 383-424

Jürgens K, Matz C (2002) Predation as a shaping force for the phenotypic and genotypic composition of planktonic bacteria. Antonie Leeuwenhoek 81:413-434

Kuuppo-Leinikki P (1990) Protozoan grazing on planktonic bacteria and its impact on bacterial population. Mar Ecol Prog Ser 63:227-238

> Labrenz M, Jost G, Jürgens K (2007) Distribution of abundant prokaryotic organisms in the water column of the central Baltic Sea with an oxic-anoxic interface. Aquat Microb Ecol 46:177-190

Labrenz M, Sintes E, Toetzke F, Zumsteg A, Herndl GJ, Seidler M, Jürgens K (2010) Relevance of a crenarchaeotal subcluster related to Candidatus Nitrosopumilus maritimus to ammonia oxidation in the suboxic zone of the central Baltic Sea. ISME J 4:1496-1508

- Lam P, Jensen MM, Lavik G, McGinnis DF and others (2007) Linking crenarchaeal and bacterial nitrification to anammox in the Black Sea. Proc Natl Acad Sci USA 104: 7104-7109

Landry MR, Lehner-Fournier JM, Sundstrom JA, Fagerness VL, Selph KE (1991) Discrimination between living and heat-killed prey by a marine zooflagellate, Paraphysomonas vestita (Stokes). J Exp Mar Biol Ecol 146:139-151

Lass HU, Prandke H, Liljebladh B (2003) Dissipation in the Baltic proper during winter stratification. J Geophys Res 108:3187

Lauterborn R (1901) Die 'sapropelische' Lebewelt. Zool Anz 24:50-55

Lin X, Scranton MI, Varela R, Chistoserdov A, Taylor GT (2007) Compositional responses of bacterial communities to redox gradients and grazing in the anoxic Cariaco Basin. Aquat Microb Ecol 47:57-72

Mamaeva NV (1988) Ciliates as a component of planktonic communities in the open regions of the Baltic Sea. Sov J Mar Biol 14:1-6

- Marie D, Brussaard CPD, Thyrhaug R, Bratbak G, Vaulot D (1999) Enumeration of marine viruses in culture and natural samples by flow cytometry. Appl Environ Microbiol 65:45-52

Marrasé C, Lim EL, Caron DA (1992) Seasonal and daily changes in bacterivory in a coastal plankton community. Mar Ecol Prog Ser 82:281-289

> Massana R, Pedrós-Alió C (1994) Role of anaerobic ciliates 
in planktonic food webs: abundance, feeding, and impact on bacteria in the field. Appl Environ Microbiol 60: 1325-1334

Medina-Sánchez JM, Felip M, Casamayor EO (2005) Catalyzed reported deposition-fluorescence in situ hybridization protocol to evaluate phagotrophy in mixotrophic protists. Appl Environ Microbiol 71:7321-7326

Mischke U (1994) Influence of food quality and quantity on ingestion and growth rates of three omnivorous heterotrophic flagellates. Mar Microb Food Webs 8:125-143

Montagnes DJS, Barbosa AB, Boenigk J, Davidson K and others (2008) Selective feeding behaviour of key freeliving protists: avenues for continued study. Aquat Microb Ecol 53:83-98

- Murray AG, Jackson GA (1992) Viral dynamics: a model of the effects of size, shape, motion and abundance of single-celled planktonic organisms and other particles. Mar Ecol Prog Ser 89:103-116

Neuer S, Cowles TJ (1995) Comparative size-specific grazing rates in field populations of ciliates and dinoflagellates. Mar Ecol Prog Ser 125:259-267

Pedrós-Alió C, Calderón-Paz JI, Gasol JM (2000) Comparative analysis shows that bacterivory, not viral lysis, controls the abundance of heterotrophic prokaryotic plankton. FEMS Microbiol Ecol 32:157-165

Pernthaler J (2005) Predation on prokaryotes in the water column and its ecological implications. Nat Rev Microbiol 3:537-546

Piwosz K, Pernthaler J (2010) Seasonal population dynamics and trophic role of planktonic nanoflagellates in coastal surface waters of the southern Baltic Sea. Environ Microbiol 12:364-377

Reissmann JH, Burchard H, Feistel R, Hagen E and others (2009) Vertical mixing in the Baltic Sea and consequences for eutrophication-a review. Prog Oceanogr 82:47-80

Saccà A, Borrego CM, Renda R, Triadó-Margarit X, Bruni V, Guglielmo L (2009) Predation impact of ciliated and flagellated protozoa during a summer bloom of brown sulfur bacteria in a meromictic coastal lake. FEMS Microbiol Ecol 70:42-53

Salat J, Marrasé C (1994) Exponential and linear estimations of grazing on bacteria: effects of changes in the proportion of marked cells. Mar Ecol Prog Ser 104:205-209

Sandén P, Håkansson B (1996) Long-term trends in Secchi depth in the Baltic Sea. Limnol Oceanogr 41:346-351

Setälä O (1991) Ciliates in the anoxic deep water layer of the Baltic. Arch Hydrobiol 122:483-492

Setälä O, Kivi K (2003) Planktonic ciliates in the Baltic Sea in summer: distribution, species association and estimated grazing impact. Aquat Microb Ecol 32:287-297

Sherr EB, Sherr BF (1993) Preservation and storage of samples for enumeration of heterotrophic protists. In: Kemp P, Sherr BF, Sherr EB, Cole J (eds) Current methods in aquatic microbial ecology. Lewis Publishers, New York, NY, p 207-212

Sherr EB, Sherr BF (2002) Significance of predation by protists in aquatic microbial food webs. Antonie Leeuwenhoek 81:293-308

Stock A, Jürgens K, Bunge J, Stoeck T (2009) Protistan diversity in suboxic and anoxic waters of the Gotland Deep (Baltic Sea) as revealed by 18S rRNA clone libraries. Aquat Microb Ecol 55:267-284

Stoeck T, Epstein S (2003) Novel eukaryotic lineages inferred from small-subunit rRNA analyses of oxygendepleted marine environments. Appl Environ Microbiol 69:2657-2663
Stoecker DK, Gifford DJ, Putt M (1994) Preservation of marine planktonic ciliates: losses and cell shrinkage during fixation. Mar Ecol Prog Ser 110:293-299

Strom SL (1991) Growth and grazing rates of the herbivorous dinoflagellate Gymnodinium sp. from the open subarctic Pacific Ocean. Mar Ecol Prog Ser 78:103-113

> Suttle CA (1994) The significance of viruses to mortality in aquatic microbial communities. Microb Ecol 28:237-243

> Taylor GT, Iabichella-Armas M, Ho TY, Scranton MI, Thunell RC, Müller-Karger F, Varela R (2001) Chemoautotrophy in the redox transition zone of the Cariaco Basin: a significant midwater source of organic carbon production. Limnol Oceanogr 46:148-163

Taylor GT, Iabichella-Armas M, Varela R, Müller-Karger F, Lin X, Scranton MI (2006) Microbial ecology of the Cariaco Basin's redoxcline: the U.S.-Venezuela Cariaco times series program. In: Neretin LN (ed) Past and present marine water column anoxia. Nato Science Series IV: Earth and Environmental Sciences. Springer, Dordrecht, p 473-499

Teira E, Reinthaler T, Pernthaler A, Pernthaler J, Herndl GJ (2004) Combining catalyzed reporter deposition-fluorescence in situ hybridization and microautoradiography to detect substrate utilization by bacteria and archaea in the deep ocean. Appl Environ Microbiol 70:4411-4414

Utermöhl H (1958) Zur Vervollkommnung der quantitativen Phytoplankton-Methodik. Mitt Int Ver Theor Angew Limnol 9:1-38

> Vázquez-Domínguez E, Peters F, Gasol JM, Vaqué D (1999) Measuring the grazing losses of picoplankton: methodological improvements in the use of fluorescently labeled tracers combined with flow cytometry. Aquat Microb Ecol 20:119-128

- Weinbauer MG, Höfle MG (1998) Significance of viral lysis and flagellate grazing as factors controlling bacterioplankton production in a eutrophic lake. Appl Environ Microbiol 64:431-438

> Weinbauer MG, Brettar I, Höfle MG (2003) Lysogeny and virus-induced mortality of bacterio-plankton in surface, deep, and anoxic marine waters. Limnol Oceanogr 48: 1457-1465

Wilhelm SW, Brigden SM, Suttle CA (2002) A dilution technique for the direct measurement of viral production: a comparison in stratified and tidally mixed coastal waters. Microb Ecol 43:168-173

Willen T (1962) Studies on the phytoplankton of some lakes connected with or recently isolated from the Baltic. Oikos 13:169-199

> Winter C, Herndl GJ, Weinbauer MG (2004) Diel cycles in viral infection of bacterioplankton in the North Sea. Aquat Microb Ecol 35:207-216

> Worden AZ, Nolan JK, Palenik B (2004) Assessing the dynamics and ecology of marine picophytoplankton: the importance of the eukaryotic component. Limnol Oceanogr 49:168-179

Yakushev E, Chasovnikov V, Murray J, Pakhomova S, Podymov O, Stunzhas P (2008) Vertical hydrochemical structure of the Black Sea. In: Kostianoy AG, Kosanev AN (eds) The Black Sea environment. The handbook of environmental chemistry. Springer, Berlin, p 277-307

Zöllner E, Hoppe HG, Sommer U, Jürgens K (2009) Effect of zooplankton-mediated trophic cascades on marine microbial food web components (bacteria, nanoflagellates, ciliates). Limnol Oceanogr 54:262-275

Zubkov MV, Sazhin AF, Flint MV (1992) The microplankton organisms at the oxic-anoxic interface in the pelagial of the Black Sea. FEMS Microbiol Ecol 101:245-250 